\title{
Competitive Advantage Strategy Development at SDIT At Taqwa Surabaya
}

\author{
Ula Mauidhotul Hasanah*, Erny Roesminingsih, \& Mudjito \\ Doctor of Education Management, State University of Surabaya, Surabaya, Indonesia \\ ula.17070845023@unesa.ac.id; ernyroesminingsih@unesa.ac.id; mudjitomudjito@unesa.ac.id \\ *Corresponding Author: uula.chazn@gmail.com | Phone Number: +6285745935778
}

\begin{abstract}
This study aims to produce a competitive advantage strategy product at the Integrated Islamic Elementary School of At Taqwa Surabaya by looking at the feasibility, practicality and effectiveness of the strategy. The approach and type of research used is development research with a descriptive quantitative approach. The data obtained in this research and development comes from the results of interviews, observations, documentation, and questionnaires filled out by expert validators and subjects who have been selected into a small group involved in the study. Data analysis was carried out by: (1) validity data analysis, (2) practicality data analysis, (3) effectiveness data analysis. This research and development resulted in a product in the form of compiling a model for developing a competitive advantage strategy at SDIT At Taqwa Surabaya that was valid, practical, and effective. The product consists of several components which include: (1) title page, (2) introduction, (3) introduction, (4) steps for implementing a competitive advantage strategy development model that must be carried out by the Principal, Deputy Principal, Field Coordinator, and Homeroom Teacher. The feasibility of the product in the form of compiling a competitive advantage strategy development model at SDIT At Taqwa Surabaya obtained the following values: (1) validity of 3.3 from a maximum value of 4 , (2) practicality of 2.87 from a maximum value of 4 , and (3) effectiveness of 2.71 of the maximum value of 4 .
\end{abstract}

Keywords: strategic management; competitive advantage; islamic elementary school;

\section{Introduction}

An educational institution whose implementation is in the form of a school should be able to provide services that satisfy the community in general and consumers of education, namely students and parents in particular, especially in a dynamic situation like today. At the same time, they can compete effectively in local, national and even global contexts. In other words, according to Nasution \& Musa (2008, October, 14) "one of the demands in education is to develop strategic and operational management which is actually widely applied in the business sector, as an anticipatory step against new trends in order to achieve and maintain a competitive position, so that later human beings who have quality resources can be produced in accordance with the needs of their time". Competition in the world of education that is so fast requires schools to think creatively, innovatively and responsively in maintaining and developing their schools. One of the efforts that can be done is to implement strategies in managing schools to improve the quality of education (Irani, Murniati, \& Khairuddin, 2014, p. 59).

Several previous studies have shown the results that there is a strong relationship between capacity development and strategic advantage of schools. Research by Wafula (2016) with the title Capability Development and Competitive Advantage of Private Primary Schools, recommends that school managers should implement competitive strategies in order to gain a sustainable competitive advantage. Competitive strategy is a formulation to increase the company's competitiveness in terms of customers or potential customers. Competitive strategy provides an advantage that distinguishes it from other companies and creates healthy competition with segmented customers (Umar, 2003: 34). Hunger and Wheelen (2003: 245) state that "competitive advantage is a collection of strategies to determine the advantage of a company from competition among other companies. Competitive strategies include low cost and differentiation. Furthermore, the combination of the two strategies is called focus.

In principle, to manage a school, to be able to improve and maintain its achievements and advantages, a strategy is needed. Based on the results of interviews conducted with the Principal during the preliminary study, SDIT At Taqwa has several strategies to become a superior school, namely by conducting solid 
teamwork (school residents) in: (1) maintaining and improving the quality of PBM through typical curriculum; (2) managing school excellence targets; and (3) improve and maintain school quality through accreditation, ISO, and school quality culture.

Through this research, an in-depth discussion will be conducted on the development of strategies carried out by schools to achieve a sustainable competitive advantage. Good cooperation from all the resources involved, will greatly determine the success of the implementation of the strategy. This research is expected to produce a description of competitive advantage strategies in schools as input and inspiration for principals, teachers, counselors, as well as education personnel and other education personnel regarding the application of excellence strategies in school management and development to face current and future competition.

\section{Literature Review}

\subsection{Strategic Management}

Hunger and Wheelen (2003) argue, "strategic management is a series of managerial decisions and actions that can determine the company's performance in the long term. Strategic management consists of environmental observation, strategy formulation, strategy implementation, and evaluation and control" (p.4). Another definition put forward by Akdon (2009), "strategic management is a comprehensive rationalization of the issues faced by the executive in his leadership in the future. Strategic management is the most accurate integration of management philosophy towards a unified and organizational approach to leadership duties" (p.16). Abdurrahman (2015) argues that, "strategic management is an art as well as a science in formulating, implementing, and evaluating strategic decisions between functions that enable organizations to achieve future goals. (p.200). Based on these several definitions of strategic management, it can be concluded that strategic management is based on observing and evaluating opportunities and threats in the environment by looking at the strengths and weaknesses of the organization/company.

\subsection{Competitive Advantage}

Wahyudi (1996) states the definition of competitive advantage/competitive advantage, "something that allows a company to earn higher profits than competitors' gains" (p.61). Wahyudi further added that "to gain a competitive advantage, an organization/company must analyze its resources to identify various weaknesses and strengths in an effort to build capabilities to achieve these advantages" (1996, p.61) Another opinion was stated by Hery (2018) in his book entitled Strategic Management that "competitive advantage is a factor that distinguishes an organization from other organizations. This differentiator can come from the core competencies possessed by the organization, where the organization has resources and capabilities that other organizations do not have" (p.66). Based on the opinions of the two figures, it can be concluded that competitive advantage is something of high value that is a distinctive characteristic in an organization/company, becomes a source of strength for the organization but can be a weakness for competitors. Companies/industry that have competitive advantages not only inherit their past glory to survive, but will always make updates and improvements so that they become leaders in certain market sectors so that they are not eroded by new competitors.

\subsection{Integrated Islamic elementary school}

Elementary school is one of the levels of formal education held to provide a strong foundation in the lower level education process. In Law No. 20 of 2003 Chapter 1, Article 1 Paragraph 8, it is stated that the level of education is the stage of education that is determined based on the level of development of students, the goals achieved, and the abilities developed. Elementary school education is an institution in the field of education that is managed by the government and the private sector which is held formally for 6 years starting from grade 1 to grade 6 for elementary school children throughout Indonesia. The intent and purpose is for the Indonesian generation to become individuals in accordance with the ideals in the 1945 Constitution (Wahyu, 2013).

Integrated Islamic School is an elementary school that implements the concept of Islamic education based on the Al-Quran and As-Sunnah. In its application, the Integrated Islamic School is defined as a school that applies its implementation approach by combining general education and religious education into a woven curriculum (Integrated Islamic School Network, 2016). The Integrated Islamic School emphasizes integration in learning methods so as to optimize the cognitive, affective and psychomotor domains. The Integrated Islamic School also combines aqliyah, ruhiyah and bodily education. In its implementation, it combines the involvement and active participation of the learning environment, namely schools, homes and communities (Integrated Islamic School Network, 2016). 
Based on these definitions, it can be concluded that the Integrated Islamic Elementary School (SDIT) is an elementary school organized by integrating Islamic values and teachings in an integrative way in the curriculum structure with an effective learning approach and optimal and cooperative collaboration between teachers and parents, as well as the community. to build the character and competence of students..

\section{Materials and Methods}

This study uses development research with descriptive quantitative approach. The research and development method or in English is called Research and Development (R\&D), according to Sugiyono (2018, p. 297) is a research method used to produce certain products and test the effectiveness of these products. Research and development according to Borg \& Gall (1983, p.772) is a process used to develop and validate educational products. This study uses steps in the form of a cycle consisting of a study of the findings of the developed product, developing the product and conducting field trials according to the background of using the product, as well as revising the results of field tests. The development model used in this study is a procedural model designed and developed by Borg \& Gall (1983, p. 775). At the development stage, Borg \& Gall used a waterfall path. The steps for developing a competitive advantage strategy that refer to the waterfall model include: (1) Research and data collection, (2) planning, (product draft development, (4) expert testing and design validation by experts, (5) revising trial results, (6) initial field trials, (7) revised trial results. Data collection methods used in developing competitive advantage strategies are through interviews, observations, documentation and questionnaires for expert validation, principals, vice principals, field coordinators, and several homeroom teachers. The expert validation questionnaire contains several indicators to evaluate the feasibility of developing a competitive advantage strategy development model. The validation questionnaire consists of content validation assessment and physical validation of competitive advantage strategic products. The data analysis techniques used in this research and development are: (1) validity data analysis, (2) practicality data analysis, (3) effectiveness data analysis.

\section{Results and Discussions}

From the results of the needs analysis obtained through interviews, observations, and questionnaires, SDIT At Taqwa wants to show the community the various advantages it has through programs implemented to survive and compete at the national and global levels. To realize these goals and ideals, SDIT At Taqwa must have the right strategy, so it is necessary to develop a competitive advantage strategy development model. These guidelines will later produce key success factors which are strategic choices that can be made by schools in achieving competitive advantage. Strategy analysis is carried out through the steps of developing a competitive advantage strategy development model that is tailored to the needs of SDIT At Taqwa Surabaya so that it is in sync with the goals to be achieved. The steps are as follows: (1) vision formulation, (2) mission formulation, (3) value formulation, (4) internal environmental analysis, (5) external environment analysis, (6) selected strategy analysis, (7) formulate strategic assumptions, (8) determine key success factors, (9) choose strategies to be implemented.

Guidelines for developing competitive advantage strategies must be validated before conducting trials in schools. Validation was carried out by Islamic elementary school consultants and strategic management experts. The validation of competitive advantage was carried out by the Consultant of SDIT At Taqwa Islamic Elementary School Surabaya. The validation of strategic management experts was carried out by a Lecturer of Educational Management, Faculty of Education, State University of Surabaya. Both of them have educational backgrounds that match the material in the products being developed. The purpose of this validation is to get criticism and suggestions so that the guidelines for developing this competitive advantage strategy become a quality product.

The results of the calculation of the score from the strategic management material expert get a score of 3.3. In accordance with the assessment criteria described in chapter iii, the formula for the level of validity used is $2.50=\mathrm{Va}<3.50$ with good information. Then the material of the product can be declared fit for use. The results of the calculation of the score from the school consultant got a score of 3.3. In accordance with the assessment criteria described in chapter iii, the formula for the level of validity used is $2.50=\mathrm{Va}<3.50$ with good information. Then the material of the product can be declared fit for use.

In the next stage, the practicality of the product was tested by assessing the fluency of the Principal, Field Coordinator and Homeroom Teacher in formulating a competitive advantage strategy development model at SDIT At Taqwa Surabaya. Based on the results of data analysis, it was found that the average practicality of the product was 2.87. Based on the assessment criteria in chapter iii, it can be concluded that the Formulation of a Competitive Advantage Strategy Development Model at SDIT At Taqwa Surabaya is declared "practical". Then the effectiveness of the product was tested by observing and assessing the Principal, Field Coordinator and Homeroom Teacher in formulating a competitive advantage strategy 
development model at SDIT At Taqwa Surabaya. The results of data analysis showed that the average product value was 2.71 . Based on the feasibility criteria described in chapter iii, it can be concluded that the formulation of a competitive advantage strategy development model at SDIT At Taqwa Surabaya is declared "effective".

The results of the validation of strategic management material experts and Islamic elementary school consultants are used as the basis for making improvements and improvements to the product. The results of the validation of each validator are then analyzed. The results of the analysis indicate that the product in the form of compiling a competitive advantage strategy model at SDIT At Taqwa Surabaya reaches good and valid criteria so that it is feasible to use. After the product is revised and approved by the expert validator, then each of the validators provides an assessment through the product feasibility form that has been provided by the researcher. The results of the calculation of the scores of each of these validators get a value of 3.3. In accordance with the assessment criteria described in chapter iii, the formula for the level of validity used is $2.50=\mathrm{Va}<3.50$ with good information. Then the material of the product can be declared fit for use.

The results of observations during the study indicate that by developing a competitive advantage strategy development model at SDIT At Taqwa Surabaya, schools can focus on determining and establishing strategies that need to be carried out in accordance with the school's vision, mission, and values in order to survive with the advantages it has and able to compete with its competitors. This is in accordance with the theory put forward by Hunger and Wheelen (2003, p. 16) regarding strategy which is a comprehensive plan of how the company will achieve its mission and goals. The strategy will maximize competitive advantage and minimize competitive limitations. In addition, Wahyudi argues that to gain a competitive advantage, an organization/company must analyze its resources to identify various weaknesses and strengths in an effort to build capabilities to achieve these advantages (1996, p.61).

The existence of a product in the form of a competitive advantage strategy development model at SDIT At Taqwa Surabaya, which contains steps in formulating strategies in accordance with the vision, mission and school values accompanied by examples in making it very practical and effective. This can be seen from the ability and convenience for the Principal, Deputy Principal, Field Coordinator and Homeroom Teacher in preparing a competitive advantage strategy development model at SDIT At Taqwa Surabaya whose steps have been described by researchers. In formulating a competitive advantage strategy development model at SDIT At Taqwa Surabaya carried out by the Principal, Deputy Principal, Field Coordinator and Homeroom Teacher by means of joint discussions with fellow research subjects, and researchers do not forget to participate in assisting.

\section{Conclusions}

The development model adopted from Borg and Gall resulted in a product in this study in the form of compiling a model for developing a competitive advantage strategy at SDIT At Taqwa Surabaya that is valid, practical, and effective. The preparation of the resulting model consists of the following components: (1) the title page contains the title, the name of the research location, the name of the university and study program, and the name of the author, (2) the introduction contains gratitude to Allah SWT for the completion of the strategy development model preparation. competitive advantage at SDIT At Taqwa Surabaya, as well as to all parties who have supported from beginning to end, (3) The introduction contains the background, basis for making, understanding, goals and benefits of developing a competitive advantage strategy development model at SDIT At Taqwa Surabaya, (4) the steps for implementing the competitive advantage strategy development model at SDIT At Taqwa Surabaya contain the stages that must be carried out by the Principal, Deputy Principal, Field Coordinator, and Homeroom Teacher in its preparation.

The feasibility of the product in the form of compiling a competitive advantage strategy development model at SDIT At Taqwa Surabaya can be described as follows: (1) the results of data analysis show that the value of product validity is 3.3 of the maximum value 4 . This means that the resulting product meets the validity criteria. Thus the resulting product is feasible to use, (2) the results of the data analysis show that the practicality value of the formulation of a competitive advantage strategy development model at SDIT At Taqwa Surabaya is 2.87 out of a maximum value of 4.3) the results of the data analysis of the effectiveness of the formulation of a competitive advantage strategy development model at SDIT At Taqwa Surabaya got a score of 2.71 from a maximum value of 4 . This means that the product has met the effectiveness criteria. The conclusion that can be drawn from these findings is that the product of developing a competitive advantage strategy development model at SDIT At Taqwa Surabaya is feasible, practical and effective to use.

The product of developing a competitive advantage strategy development model at SDIT At Taqwa Surabaya has met the eligibility criteria, so it can be used as a reference in making the right strategy in accordance with the vision, mission, and values at SDIT At Taqwa Surabaya. Product analysis that produces the value of validity, practicality and effectiveness of the formulation of a competitive advantage strategy 
development model at SDIT At Taqwa Surabaya has not been maximized, so it can still be improved. In order to increase the feasibility of the product, it needs to be tested on a wider subject and environment.

\section{Acknowledgement}

The author would like to thank the supervisors from the Education Management Study Program of the State University of Surabaya who have assisted in completing this research. The author would also like to thank the principal of the integrated Islamic elementary school At Taqwa Surabaya who has been pleased to give permission for the collection of research data at the school, as well as everyone who participated in the completion of this research.

\section{Author's Contribution}

All authors were involved in the preparation and discussion of research results and contributed from the beginning of proposal preparation, data collection, to the final research report.

\section{Conflict of Interest}

The authors declare that there are no parties who have competing interests in the process of preparing this research.

\section{References}

Abdurrahman \& Herdiana, Nana. (2015). Manajemen Strategi Pemasaran. Bandung: Pustaka Setia.

Akdon. (2009). Strategic Management for Educational Management. Bandung: Alfabeta.

Amrullah, Muhammad Amin. (2017). Implementasi Manajemen Strategik di Sekolah Unggulan SMP Negeri 3 Tuban (Tesis Master Tidak Dipublikasikan). Universitas Negeri Surabaya, Surabaya, Indonesia.

Arifin, Zainal. (2011). Konsep dan Model Pengembangan Kurikulum. Bandung: PT. Remaja Rosdakarya.

Ashour, Mohammed Luthfi. (2018). Schools Thought of Competitive Advantage. International Journal of Bussiness and Management Invention (IJBMI), 7(2), 2319-8028.

Bashori. (2017). Strategi Kompetitif Dalam Lembaga Pendidikan, Tadris 12(2). Diperoleh dari http://ejournal.stainpamekasan.ac.id/index.php/tadris /article/download/1269/1065.

Bisaria, Gaurav. (2013). Achieving Competitive Advantage by Private Management Colleges or Private Universities. International Journal of Social Science \& Interdisciplinary Research (IJSSIR), 2(3), 22773630.

Budi, Kurniasih. (2018, Febuari 8). Ini Rekomendasi Penting untuk Ubah Dunia Pendidikan di Indonesia. Kompas. Diperoleh dari https://edukasi.kompas.com/read/2018/02/08/09050021/ini-rekomendasi-penting-untuk-ubahdunia-pendidikan-di-indonesia.

David, Fred R. (2006), Manajemen Strategis. Salemba Empat: Jakarta.

Gunawan, Imam. (2009). Manajemen Strategik dalam Pendidikan. Diperoleh dari website Blogspot: http:/ / masimamgun.blogspot.com/2009/02/manajemen-strategik-dalam-pendidikan.html.

Hamalik, Oemar. (2010). Manajemen Pengembangan Kurikulum. Bandung: P.T Remaja Rosdakarya

Hermini, Agustinus. (2014). Manajemen Kurikulum Berbasis Karakter. Bandung: Alfabeta.

Hery. (2018). Manajemen Strategik. Jakarta: PT Grasindo.

Hitt, Michael A. dkk. (2001). Manajemen Strategis, Daya Saing dan Globalisasi. Jakarta: Salemba empat.

Hunger, David J \& Wheelen, Thomas L. (2003). Manajemen Strategis. Yogyakarta: Andi.

Kamau, Simon Mwaura. (2013). Competitive Strategies Adopted by Private Universities in Kenya. Diperoleh dari .https://pdfs.semanticscholar.org/0af4 /411a204e6fb32e002de170c381bfc1e47320.pdf

Kamayuda, DMD., \& Krismanda, M.A. (2016). Perencanaan Strategi Bersaing Sekolah dalam Meningkatkan Mutu Pendidikan di Sekolah Swasta Salatiga. Satya Widya, 32(2), 79-91. Diperoleh dari http://ejournal.uksw.edu/ satyawidya/article/download/722/483/

Kompri. (2015). Manajemen Sekolah. Yogyakarta: Pustaka pelajar.

Laudon, Kenneth C \& Jane P. Laudon. (2007). Sistem Informasi Manajemen, Mengelola Perusahaan Digital Buku 1 Edisi 10. Jakarta: Salemba empat.

Mainardes, E.W., Tontini, G., Ferreira, JM., \& Tontini, G. (2011). Creating a Competitive Advantage in Higher Education Institutions: Proposal and Test of a Conceptual Model. International Journal of Management in Education, 5(2/3), pp. 145-168, 10.1504/IJMIE.2011.039482. 
Mazzarol, T., \& Soutar, G. (1999). Sustainable Competitive Advantage for Educational Institutions: A Suggested Model. International Journal of Education Management, 13(6): 287-300. doi: 10.1108/09513549910294496

Moleong, Lexy J. (2012). Metodologi Penelitian Kualitatif. Bandung: P.T Remaja Rosdakarya.

Muhardi. (2004). Aspek-aspek Keunggulan Bersaing Perguruan Tinggi, 20(2), 179-193. Diperoleh dari https://ejournal.unisba.ac.id/index.php/mimbar/ article/view/135.

Musa, Faisal, \& Nasution, A.S. (2008). Manajemen Strategi dan Operasi dibidang Pendidikan. Diperoleh dari website Wodpress:https://sanoesi.wordpress.com/2008/10/14/manajemen-strategi-dan-operasi-dibidang-pendidikan/.

Nadlir, Moh. (2018, Mei 2). Komnas HAM Catat 4 Kondisi Darurat Pendidikan Indonesia. Diperoleh dari https://nasional. kompas.com /read/ 2018/05/02 /12581141/komnas-ham-catat-4-kondisi-darurat-pendidikanindonesia.

Ningrum, Nurita K. (2016). Strategi Keunggulan Bersaing pada Lembaga Pendidikan dan Pelatihan Magistra Utama Jember. (Tesis Master Universitas Jember), diperoleh dari http://repository.unej.ac.id/bitstream/handle/ 123456789/75922/Nurita\%20Kustiari\%20Ningrum\%20\%20110920101004.pdf?sequence=1.

Patton, Michael Quinn. (2009). Metode Evaluasi Kualitatif. Yogyakarta: Pustaka Pelajar

Porter, Michael E. (1980). Strategi Bersaing: Teknik Menganalisis Industri dan Pesaing. Jakarta: Erlangga

Porter, Michael E. (1985). Competitive Advantage: Creating and Sustaining Superior Performance. New York: Macmillan.

Porter, Michael E. (1985). Keunggulan Bersaing: Menciptakan dan Mempertahankan Kinerja Unggul. Jakarta: Erlangga.

Purnama, Sandhy. (2018). Strategi Meraih Keunggulan Bersaing Berkelanjutan (Sustainable Competitive Advantage) Berbasis Model Resource-Based View. (Tesis Master Unpas), diperoleh dari http://repository.unpas.ac.id/14146/1/ jurnal\%20tesis.docx.

Reksoatmojo, Tedjo Narsoyo. (2010). Pengembangan Kurikulum Pendidikan. Bandung: PT. Refika Aditama

Riyanto, Yatim. (2001). Metodologi Penelitian Pendidikan. Surabaya: SIC.

Riyanto, Yatim. (2007). Metodologi Penelitian Pendidikan, Kualitatif dan Kuantitatif. Surabaya: Unesa University Press.

Rojak, Adi Irpan. (2017). Implementasi Perencanaan Strategis dalam Meningkatkan Mutu Pendidikan Madrasah Swasta. (Tesis Master Universitas Islam Negeri Maulana Malik Ibrahim), diperoleh dari http://etheses.uinmalang.ac.id/9746/1/15710012.pdf.

Rusman. (2012). Manajemen Kurikulum. Jakarta: Rajawali Pers

Schuler, Randal S. \& Jackson, Susan E. (1996). Manajemen Sumber Daya Manusia Menghadapi Abad ke 21 Jilid 2, Edisi Keenam. Jakarta: Penerbit Erlangga.

Strategi Bersaing dalam Bisnis Pendidikan. Diperoleh pada Januari 26, 2019 dari http://staff.uny.ac.id/sites/default/files/strategi\%20bersaing\%20dalam\%20bisnis\%20pendidikan.pdf

Sugiyono. (2017). Metode Penelitian Kualitatif. Bandung: Alfabeta

Sukmadinata, Nana Syaodih. (2010). Pengembangan Kurikulum Teori dan Praktek. Bandung: P.T Remaja Rosdakarya.

Tia, N., Dwi, K., Imas, S., \& Yunizar. (2016). The Achievement of Competitive Advantage Through Quality of Service at High Schools in West Java Province, Indonesia. International Journal of Economics, Commerce, and Management. 4(12), 23480386.

Triwiyanto, Teguh. (2015). Manajemen Kurikulum dan Pembelajaran. Bumi aksara: Jakarta.

Umar, Husein. (2003). Strategik Manajemen In Action. Jakarta: PT. Gramedia Pustakama

Undang-undang Republik Indonesia Nomor 20 Tahun 2003 Tentang Sistem Pendidikan Nasional. 2010. Bandung: Citra Umbara.

Wafula, Silas Opicho. (2016). Capability Development and Competitive Advantage of Private Primary Schools in Mombasa County. Diperoleh dari

https://pdfs.semanticscholar.org/f4de/094fc290533e92433b92a55a39b4110f9412.pdf.

Wahyudi, Agustinus Sri. (1996). Manajemen Strategik. Jakarta: Binarupa aksara.

Yin, Robert K. (2011). Studi Kasus Desain dan Metode. Jakarta: P.T Raja Grafindo Persada.

Z, Irani U., AR, Murniati., \& Khairuddin. (2014). Implementasi Manajemen Strategik dalam Upaya Peningkatan Mutu Pendidikan pada SMAN 10 Fajar Harapan. Jurnal Administrasi Pendidikan, 4(2): 58-70. 